\title{
The implementation of evaluation in Science learning based on \\ Problem Based Learning (PBL) for 3rd graders \\ during Covid-19 pandemic outbreak
}

\author{
${ }^{1}$ Ofta Dwi Purwantini, ${ }^{2}$ Wahyu Lestari \\ 10ftadwi22@students.unnes.ac.id \\ 1,2Elementary Education Department, Postgraduate Program, \\ Universitas Negeri Semarang
}

\begin{abstract}
This study aimed to analyze the implementation of evaluation in Science learning at 3rd grade in SD IT Asshodiqiyah Semarang. This study used the qualitative method and collected data through observation, interview and documentation. The data source of the study was the teacher, parents, and students. During the Covid-19 pandemic outbreak, SD IT Asshodiqiyah conducted learning through the WhatsApp platform. The result of the study obtained some findings as follows: (1) PBL-based learning evaluation was appropriate to implement in Science learning, (2) PBL-based evaluation was conducted according to the objectives of learning by following simple yet challenging learning stages for students to involve in active participation, (3) evaluation in Science learning were in portfolio-based model, practice-based model, and cognitive-based model by using WhatsApp platform and Google Form feature. Nevertheless, the authors found some obstacles in the implementation, such as the lack of parents' and student enthusiasm, the lack of parent understanding on how to implement the evaluation model, and the lack of cooperation between teacher and parents. The solution for the problem was that teachers and parents should have good communication and mutual agreement regarding the evaluation process.
\end{abstract}

Keywords: evaluation; Science learning, Problem Based Learning (PBL), pandemic Covid-19

Received: May 28 $8^{\text {th }}, 2021 \quad$ Reviewed: May 31 ${ }^{\text {st }}, 2021 \quad$ Accepted: July 22 ${ }^{\text {nd }}, 2021 \quad$ Published: July $31^{\text {st }}$, 2021

\section{INTRODUCTION}

The COVID-19 pandemic has a significant impact in various fields of human life. Human activities have totally changed, experiencing new habits, namely social distancing, where human activities are only carried out from home through the network. The social distancing policy implemented aims to limit human interaction and prevent crowds so that people avoid the spread of the coronavirus (Syarifudin, 2020). This policy has an impact on learning activities, especially in the context of the face-to-face learning that is suddenly paused. Face-to-face learning is replaced with an online learning system through existing learning applications. Inevitably, changes in the learning process must be accepted by all parties including teachers, students and parents due to conditions that do not allow. Online learning that does 
not know when it will end creates anxiety and boredom so that the online learning process that is applied is not optimal. Teachers, students, and parents find it difficult with changes in online learning systems. The difficulties experienced in online learning involve several things, namely the use of strategies, media, materials, learning administration, and learning evaluation.

This study focuses on evaluating Science (Ilmu Pengetahuan Alam/IPA) learning during the COVID-19 pandemic outbreak. Learning evaluation is a process of systematically collecting and analyzing data to find out evidence of the students' assignment in the learning, the achievement of learning objectives and determining the effectiveness of the learning process (Riadi, 2017). Another view of evaluation is that evaluation is a deliberate activity conducted through careful planning to measure objects or to find out the scores obtained by the students after participating in a series of learning activities for some time (Fitrianti, 2018). Evaluation is important in the teaching process to find out students' views and understanding of a material (Linse, 2017). Based on some of these opinions, it can be concluded that learning evaluation is an activity that is conducted systematically and organized to measure and assess students' understanding, and the achievement of learning objectives which are used as benchmarks for making improvements.

Evaluation of online learning is difficult. The obstacle lies in the difficulty of providing supervision during the evaluation because the teacher is not near to the students, the difficulty of applying the principle of objectivity because the evaluation is carried out in their respective homes, and the difficulty of teaching honesty to the students because the evaluation is conducted with the assistance of parents. Consequently, the quality of the learning evaluation is not optimal. Teachers and parents feel helpless to overcome these problems, because the conditions do not allow and the facilities used are as they are.

It is difficult to evaluate online learning. However, evaluation activities cannot be avoided or left behind in learning. Conditions compel, inevitably, evaluations are still held and carried out, because evaluation functions to measure the achievement of students' competencies (Farida \& Lestari, 2020), measure and assess the success of the learning process and measure the achievement of student competencies towards the learning objectives used to reference to make improvements and improve the quality of learning. The implementation of evaluation of science learning must refer to the principles of evaluation, namely practicality, reliability, validity and authenticity (Nuriyah, 2014). 
The process of online learnning in elementary school covers various subjects, one of them is Science (Ilmu Pengetahuan Alam/IPA). Science learning is a kind of learning that provides direct experience to students in order to understand nature scientifically so that it could improve cognitive, psychomotor and social thinking skill (Prabowo, 2015). Science learning should emphasize on student activities during the learning process to construct knowledge through various activities in order to create a meaningful learning for students (Fuadi et al., 2015). Science learning insists on direct experiences for students to develop their potentials, so that they could understand natural environment through observation and analysis process to gain experiences on natural environment (Handayani \& Jumadi, 2021). The Covid-19 outbreak gives some new experiences in Science learning process, especially in the process of evaluation. The evaluation of Science learning is a highly structured evaluation, which means that the evaluation on students should be based on the learning process provided by the teacher, so that the evaluation and the objective of learning could be in the same direction (Ramdani et al., 2019). Furthermore, the evaluation is vital and inseparable in the learning. The evaluaton in Science learning could be used as a consideration to improve the process of Science learning.

Learning evaluation activities during the pandemic require an alternative that is used to implement the evaluation of Science learning during the pandemic outbreak. Evaluation of Science learning based on Problem Based Learning (PBL) was an innovation used by SD IT Asshodiqiyah teachers which emphasizes the problems of students' experiences with the natural environment. However, the implementation of the evaluation of Science learning based on Problem Based Learning (PBL) has not been conducted optimally because it was constrained by limited human resources and facilities.

Problem Based Learning (PBL) is a learning method for training students' critical thinking to solve problems directly in reality (Mulyani, 2020). Problem Based Learning method is one of the methods recommended by the government in implementing the teaching and learning process. Based on previous research, it indicated that the Problem Based Learning learning method could improve student learning outcomes by using test and non-test evaluation tools (Nuraini \& Kristin, 2017). Problem Based Learning (PBL) method is a learning method that trains students to think critically to solve problems directly in reality (Mulyani, 2020). Steps for Problem Based Learning (PBL) implementation include: the existence of a 
problem, statement of what is known, statement of problems, knowledge studies, investigating solutions, presenting and supporting the determined solutions, and reviewing performance (Barak, 2020). Problem Based Learning method is considerably very effective in the distance/online learning process.

Previous studies had explained some difficulties in implementing learning evaluations during the pandemic including the difficulty in determining the form of evaluation, the difficulty of mapping indicators as a basis for evaluation (Damanik et al., 2020). Learning evaluation could be conducted by applying an evaluation model in form of online-based tests, portfolios, and self assessments (Ahmad, 2020). Another previous study had explained that the learning method must be in accordance with existing conditions. A study at Australia University indicated that the use of the Problem Based Learning (PBL) method could improve student learning outcomes in the online learning process (McMillan, 2020).

Purpose of this study was to determine the implementation of evaluation in Science learning based on PBL at 3rd grade in SD IT Asshodiqiyah during the Covid19 pandemic outbreak. The study is important to conduct as the PBL-Based learning evaluation could grant benefits to determine the ease and obstacle in Science learning during the pandemic outbreak. Thus, this study focused on the implementation of evaluation in Science learning based on PBL at 3rd greade in SD IT Asshodiqiyah during the Covid-19 pandemic outbreak.

\section{METHOD}

Method used in this research was a qualitative research method. Qualitative method is used to describe phenomena or facts in the field as they are, meaning that PBL-based Science learning evaluation models would be described at SD IT Asshodiqiyah Semarang during the Covid-19 pandemic. This method is limited to description. In terms of analysis, the authors only provided an interpretation of the facts or data found. This type of descriptive study research is indeed quite appropriate to use if the research objective is limited to the real depiction of the findings in the field, not to testing and so on. As for those who will be the sources in this research: (1) educators/teachers; the data obtained through interviews was in the form of information about the PBL-based Science evaluation models implemented during the Covid-19 pandemic which was used as an alternative in terms of assessing and measuring the achievement of learning objectives. (2) parents; data obtained from parents was in the form of information about the 
obstacles faced during online learning during the Covid-19 pandemic. This data source was used as the initial basis for the emergence of the PBL-based learning evaluation model. (3) Students; data obtained from students was in the form of information related to the interest and motivation in taking online-based Science learning, and the obstacles they faced while participating in online-based Science learning.

The authors collected data through interviews, observation, and documentation (Sugiyono, 2013). It was impossible to collect data about the learning process directly in face-to-face meetings in the classroom during the Covid-19 outbreak. The authors conducted observations through video calls or video recordings created by the teachers and sent via WhatsApp Group. Besides, interviews with the teachers were conducted directly, or face-to-face interview. Collecting data from parents and students was conducted directly by visiting their houses. The data obtained would be analyzed descriptively.

\section{RESULT AND DISCUSSION}

The explanation of the result of this study adjusted to the focus of the study: the implementation of the evaluation of Science learning based on Problem Based Learning (PBL) method at SD IT Asshodiqiyah Semarang during the Covid-19 pandemic outbreak as follows:

\section{Evaluation in Science Learning}

Evaluation in general could be defined as a systematic process to determine the value of something (rule, activities, decision, performance, process, and objects) based on certain criteria through an assessment (Mahirah, 2017). Evaluation could also be defined as measurement and assesment. It is said to be measurement if the data is presented in the form of numbers. Meanwhile, it is said to be an assessment when it is related to the interpretation of the numerical data itself. Evaluation in learning has two functions: assessment on program achievement and learning objectives, and measurement on students' competence achievement. The existence of evaluation makes it easier for teachers to improve the quality of learning that has been implemented. For this part, this study focused on the evaluation in the measurement of students' learning outcome.

Learning evaluation could be found in all subjects, including Science subject. Evaluation of Science subject is the main focus, to determine the extent to which the Science learning program had been achieved during the Covid-19 pandemic 
outbreak. The situation led by pandemic forces educators to think creatively to keep the learning process going on. Every human being has creativity and it requires stimulants to work optimally (Sugiarto \& Lestari, 2020). Evaluation during the pandemic outbreak had not been implemented optimally. Evaluation in Science learning at SD IT Asshdodiqiyah Semarang used the WhatsApp application.

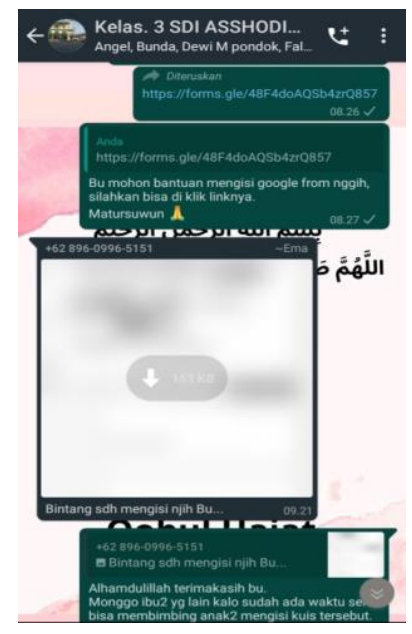

Figure 1. Evaluation of Learning through WhatsApp

The evaluation model of Science learning in SD IT Asshodiqiyah Semarang was conducted by just giving assignments via the WhatsApp application. The evaluation sent via WhatsApp was in form of written test questions in multiple choice type. Apart from going through WhatsApp, the evaluation of Science learning was also conducted through Google Form by distributing the link via WhatsApp. Evaluation via Google Form was unfortunately often ignored by students.

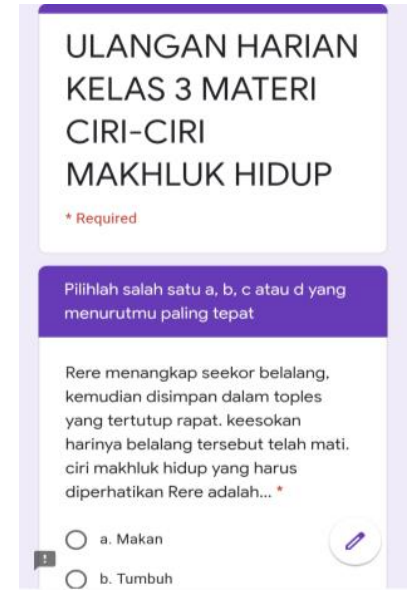

Figure 2. Evaluation of Learning through Google Forms 
This was due to the lack of understanding of parents in using the Google Forms, while the implementation of the Google Form had a limited time. The process of evaluating Science learning took about 15 hours, from the time the teacher gave the link from 07.30 to $22.00(\mathrm{UTC}+7)$. As the evaluation took a long time, there was no guarantee that all students were actively working on the questions. Some students often ignored the evaluation because they did not have their own smartphone so they used their parents' smartphone.

\section{Model of Evaluation in PBL-Based Science Learning}

Evaluation model is a model that is determined based on the program and objectives. The data obtained regarding the evaluation model is the result of data collection through interviews with 3rd grade teachers in SD IT Asshodiqiyah Semarang.

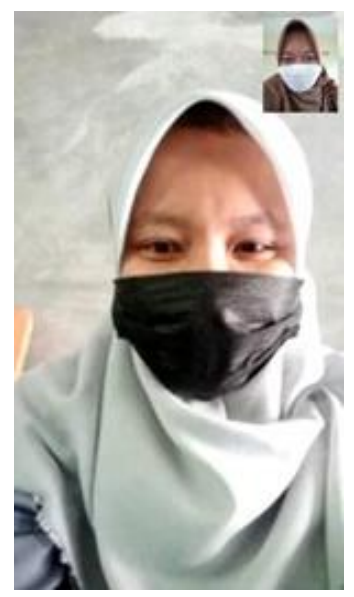

Figure 3. Interview with the teacher

The authors chose the evaluation model based on the program and purpose/objectives. The following explanation is about evaluation models which the implementation is based on Problem Based Learning. Some of the evaluation models for Science learning during the Covid-19 pandemic could be as follows:

a. Portfolio Based Evaluation

Portfolio based evaluation is one of learning evaluation models. The making of a portfolio based evaluation is adjusted to the learning objectives in the lesson plan (RPP). The writing of learning objectives relating to portfolio based evaluation could refer to the formulas A, B, C, and D (Pramono et al., 2021) with the following details: A means Audience, the 
audience here means students that could be as subject and object; B means Behavior, students' behavior expected after the learning. The writing of Behavior in learning objectives uses verbs in the form of analyzing, identifying, etc.; C means Condition relating to real conditions in the learning process; D means Degree is the achievement of a series of learning processes.

Portfolio based evaluation model during the Covid-19 pandemic outbreak could be in the form of documents stored in a folder containing students' daily tasks which were then collected into a portfolio. The selection of this evaluation model was adjusted to the Problem Based Learning method during this pandemic outbreak. PBL-based portfolios contained solving problems presented by the teacher based on the students' environment. Portfolio evaluation during this pandemic could be in the form of student reports of experimental assignments and analysis that students conducted at home.

b. Practice Based Evaluation

Practice evaluation model in Science learning during the pandemic outbreak was still being conducted, because the learning competence required psychomotor aspects, although there are some aspects to teach in Science learning. The process of practice evaluation in Science in SD IT Asshodiqiyah was conducted online during the pandemic outbreak. The teacher provide a tutorial video about what to do for students. After that, the students should send the result of their experiments thorugh WhatsApp in form of videos or photo documentation. In the video, the students could explain their experiment result. It was in line with the process of learning based on Problem Based Learning method.

c. Cognitive Based Evaluation

This intellectual based learning evaluation model deals with students' metacognitive skills. Metacognitive is a person's ability to understand how to learn, the ability to understand the difficulty of problems, the ability to use information to achieve goals (Lestari et al., 2019). The metacognitive ability could be seen by using evaluation tools: tests and nontests. Evaluation tests that were conducted in each subject, at the end of the semester, became quite urgent in its position and function to measure the level of students' ability and understanding (Mujianto, 2017). The evaluation activities must always be conducted actually at the end of the lesson, in 
order to assess to what extent the level of knowledge mastery given and absorbed by students. In Science learning at SD IT Asshodiqiyah Semarang, the authors conducted a process of evaluation in the form of written tests. In the beginning of the process, the teacher sent a Google Form link to WhatsApp Group containing problem-based questions through the WhatsApp Group. The intellectual-based evaluation with test type evaluation using a limited time, this aimed to prevent cheating in working on evaluation questions.

\section{Obstacles in the Implementation of the PBL-Based Science Learning} Evaluation Model During the Covid-19 Pandemic Outbreak

Evaluation of PBL-based Science learning that had been implemented in SD IT Asshodiqiyah Semarang could not deny the fact that there were obstacles or problems faced by the parents of students in the process. Information about the obstacles in the implementation of PBL-based Science learning evaluation was obained from the result of interviews with parents of 3rd grade students in SD IT Asshodiqiyah.

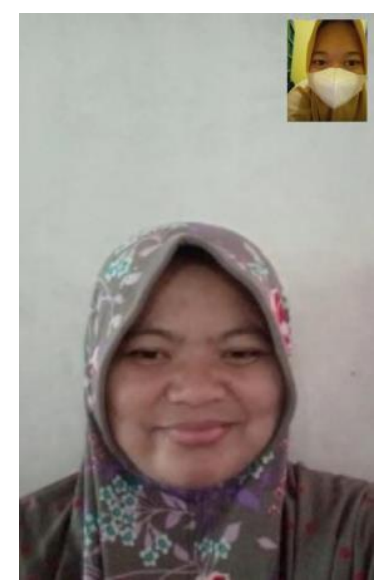

Figure 4. Interview with Parent

The obstacles experienced by the parents of students are described as follows:

a. Lack of cooperation between teachers and parents

Cooperation between teachers and parents is the most fundamental thing in the Science learning process during this pandemic outbreak. Especially in the evaluation process, collaboration with parents is the key to 
the success of the evaluation system. Lack of cooperation and communication between teachers and parents in the implementation of evaluation in Science learning during the pandemic outbreak, such as (1). Limited time for parents in accompanying children to study, (2). The assistance provided by parents was not in form of accompaniment in terms of evaluation, but is in the nature of providing full support, (3) the parents were reluctant to follow the procedural directions given by the teacher, (4) the parents did not comply with regulations that have been mutually agreed upon.

Based on interviews conducted with some parents, it could be concluded that the reasons for the lack of parental accompaniment in the students' learning process were: (1) Lack of time for parents to accompany their children in studying due to their own business, (2) Lack of parents' ability in using application for the sake of evaluation, (3) Lack of parents' understanding in online learning, which often led to misconceptions.

b. Lack of Parents and Students Enthusiasm

The lack of parents' enthusiasm occurred because of a sudden change in the evaluation model, so the parents had to learn how to use the application of the evaluation model for Science learning during the Covid-19 pandemic outbreak. Parents found it difficult as usually parents only sent their children to school and picked them up home. However, it changed recently. Changes in the evaluation model were also complicated for most parents and unfortunately led to a great sense of ignorance and tended to be unenthusiastic in implementing the evaluation of Science learning.

Parents' enthusiasm brings great impact in student motiation to conduct evaluation. There are some reasons of unenthusiasm in the implementation of evaluation in PBL-based Science learning, such as the high number of homeworks, or the difficulty to understand the material delivered by the teacher. It had been underlined in the study by (Kurniasari et al., 2020) indicating that obstacles students had to face in online learning was the high number of homeworks, high number of materials, difficult accessibility to learning video and unclear instruction from teachers.

c. Lack of parents' understanding in the implementation of the evaluation model 
Most parents often felt that the PBL-based evaluation model in Science learning evaluation model was considerably difficult. The difficulty was that parents did not understand the instructions and procedures for implementing the evaluation of Science learning. This was due to the lack of parents' understanding in using smartphones, so that they could not help their children optimally. In addition, lack of teacher's explanation about the PBL-based evaluation model in Science learning was another cause of obstacles in the learning process.

\section{Solution for the Implementation of PBL-Based Science Learning Evaluation at 3rd Grade in SD IT Asshodiqiyah During the Covid-19 Pendemic Outbreak}

Authors and teachers of 3rd grade in SD IT Asshodiqiyah had conducted interviews and discussion relating to the solution for the implementation of PBL-based Science learning evaluation at 3rd grade during the pandemic outbreak. Based on obstacles in the process of the evaluation, discussion between the authors and the teachers come up with some solutions. First, if the cooperation between the teacher and parents does not work well, both parties should make an agreement relating to the process of learning evaluation during the pandemic outbreak, for example the teacher uses application that is easy to use by parents for the implementation of evaluation. If it does not work, the parents should ask assistance from neighbors or relatives who understand how to use the application in the implementation of evaluation. The last option is to conduct offline learning with the students at school within strict health protocol during the Covid-19 pandemic outbreak.

\section{CONCLUSION}

Covid-19 pandemic outbreak has caused significant changes in education. It surely brings much impact on the implementation of evaluation for teachers, parents and students as well. Furthermore, teachers in SD IT Asshodiqiyah Semarang implemented evaluation in Science learning based on Problem Based Learning (PBL) to give positive impression in the learning process. The evaluation in PBL-based Science learning was in form of portfolio evaluation model, practice evaluation model, and cognitive evaluation model. Obstacles in the implementation of PBL-based Science learning evaluation during the pandemic outbreak were the 
lack of cooperation between teacher and parent, and the lack of student and parent enthusiasm. However, solution for the problem was that both teacher and parent should communicate and discuss an agreement relating to the process of evaluation.

\section{REFERENCES}

Ahmad, I. F. (2020). Asesmen alternatif dalam pembelajaran jarak jauh pada masa darurat penyebaran Coronavirus disease (Covid-19) di Indonesia. PEDAGOGIK: Jurnal Pendidikan, 7(1), 195-222. https://doi.org/10.33650/pjp.v7i1.1136

Barak, M. (2020). Problem-, Project- and Design-Based Learning: Their relationship to teaching Science, Technology and Engineering in school. Journal of ProblemBased Learning, 7(2), 94-97. https://doi.org/10.24313/jpbl.2020.00227

Damanik, S., Zuhdi, M., \& Herlina, H. (2020). Model evaluasi pembelajaran AUD berbasis daring di RA Nurun Namirah Medan Marelan (Studi kasus selama masa pandemi Covid-19). Al-Fatih: Jurnal Pendidikan Dan Keislaman, 3(1), 157.

Farida, H., Haryono, \& Lestari, W. (2020). Development of speaking skill assessment instruments on learning Indonesian language android-based at Primary School. Educational Management, 9(1), 1-8.

Fitrianti, L. (2018). Prinsip kontinuitas dalam evaluasi proses pembelajaran. Jurnal Pendidikan, 10(1), 89-102.

Fuadi, Sumaryanto, T., \& Lestari, W. (2015). Pengembangan instrumen penilaian psikomotor pembelajaran IPA materi Tumbuhan Hijau berbasis Starter Experiment Approach berwawasan konservasi. Journal of Research and Educational Research of Evaluation, 4(1), 1-11.

Handayani, N. A., \& Jumadi. (2021). Analisis pembelajaran IPA secara daring pada masa pandemi Covid-19. Jurnal Pendidikan Sains Indonesia, 9(2), 217-233.

Kurniasari, A., Pribowo, F. S. P., \& Putra, D. A. (2020). Analisis efektivitas pelaksanaan Belajar dari Rumah (BDR) selama pandemi Covid-19. Jurnal Review Pendidikan Dasar: Jurnal Kajian Pendidikan Dan Hasil Penelitian, 6(3), $1-8$.

Lestari, W., Selvia, F., \& Layliyyah, R. (2019). Pendekatan Open-Ended terhadap kemampuan metakognitif siswa: Alternatif pembelajaran di Kurikulum 2013. At-Ta'li, 5(2), 93-106.

Linse, A. R. (2017). Interpreting and using student ratings data: Guidance for faculty serving as administrators and on evaluation committees. Studies in Educational Evaluation, 54, 94-106. https://doi.org/10.1016/j.stueduc.2016.12.004

Mahirah. (2017). Evaluasi belajar peserta didik (Siswa). Idaarah: Jurnal Manajemen Pendidikan, 1(2), 257-267. https://doi.org/10.24252/idaarah.v1i2.4269

McMillan, M. (2020). COVID19 - The catalyst for educational change: Applying/using E-PBL for accelerated change. Journal of Problem-Based Learning, 7(2), 51-52. https://doi.org/10.24313/jpbl.2020.00297

Mujianto, S. (2017). Analisis daya beda soal. taraf kesukaran, butir tes, validitas butir tes, interpretasi hasil tes valliditas ramalan dalam evaluasi pendidikan. Jurnal Manajemen Dan Pendidikan Islam 2, 2(2), 192-213.

Mulyani, S. (2020). Penerapan metode pembelajaran Problem Based Learning guna meningkatkan hasil belajar IPA di masa pandemi Covid 19. Navigation Physics: Journal of Physics Education, 2(2), 84-89. https://doi.org/10.30998/npjpe.v2i2.489

Nuraini, F. (2017). Penggunaan model Problem Based Learning (PBL) untuk meningkatkan hasil belajar IPA siswa kelas 5 SD. Jurnal Mitra Pendidikan, 1(4), 
369-379. https://doi.org/10.1080/10889860091114220

Nuriyah, N. (2014). Evaluasi pembelajaran: Sebuah kajian teori. Jurnal Edueksos, 3(1), 73-86.

Prabowo, S. A. (2015). The effectiveness of scientific based learning towards science process skill mastery of PGSD students. Jurnal Pendidikan IPA Indonesia, 4(1), 15-19.

Pramono, D., Ngabiyanto, Isnarto, Saputro, I. H., \& Utomo, A. P. Y. (2021). Optimalisasi model pelatihan terpadu dalam penyusunan ebook pembelajaran sebagai implementasi paperless bagi guru di SMPN 41 Semarang. Jurnal Implementasi, 1(1), 1-9.

Ramdani, A., Jufri, A. W., Gunawan, G., Hadisaputra, S., \& Zulkifli, L. (2019). Pengembangan alat evaluasi pembelajaran IPA yang mendukung keterampilan abad 21. Jurnal Penelitian Pendidikan IPA, 5(1). https://doi.org/10.29303/ippipa.v5i1.221

Riadi, A. (2017). Problematika sistem evaluasi pembelajaran. Jurnal Ittihad, 15(27), $1-12$.

Sugiarto, E., \& Lestari, W. (2020). The collaboration of visual property and semarangan dance: A case study of student creativity in "Generation Z." International Journal of Innovation, Creativity and Change, 10(12), 100-110.

Sugiyono. (2013). Metode Penelitian Kuantitatif, Kualitatif dan R\&D. Alfabeta.

Syarifudin, A. S. (2020). Impelementasi pembelajaran daring untuk meningkatkan mutu pendidikan sebagai dampak diterapkannya social distancing. Jurnal Pendidikan Bahasa Dan Sastra Indonesia Metalingua, 5(1), 31-34. https://doi.org/10.21107/metalingua.v5i1.7072

Conflict of Interest Statement: The authors declare that the research was conducted in the absence of any commercial or financial relationships that could be constructed as a potential conflict of interest. 